\title{
Correlation of serum betatrophin levels with disease severity and the emergence of insulin resistance in cirrhotic patients
}

\author{
Mohamed Magdy Salama', Walaa Ahmed Kabiel², Silvia Shoukry Hana ${ }^{1}$ and Ghada Abdelrahman Mohamed ${ }^{1 *}$ (D)
}

\begin{abstract}
Background: Insulin resistance (IR) is frequently associated with chronic liver disease. There has been an increased interest in betatrophin protein and its involvement in the compensatory response to IR. We aimed to investigate the correlation of serum betatrophin levels with disease severity and the emergence of IR in cirrhotic patients. This study included 27 cirrhotic patients and 30 healthy participants who served as a control group. IR was assessed by the Homeostasis Model Assessment (HOMA-IR). Serum insulin and betatrophin levels were measured using EnzymeLinked Immunosorbent Assay (ELISA).

Results: IR was existing in 74\% of cirrhotic patients $(p<0.001)$. Subjects with IR had higher serum betatrophin levels than those without IR ( $p=0.04)$. Serum betatrophin levels were significantly higher in cirrhotic patients than controls $(p<0.001)$. In addition, Child-Pugh class $C$ patients had higher serum betatrophin levels than those with Child-Pugh class B cirrhosis $(p=0.01)$. Moreover, the highest serum betatrophin levels were detected in patients with tense ascites followed by those with moderate and mild ascites $(p=0.01)$. In the cirrhosis group, serum betatrophin levels correlated positively with fasting blood glucose levels $(p<0.001)$, fasting insulin levels $(p=0.006)$, HOMA-IR ( $p=$ $0.006)$, Child-Pugh score $(p=0.023)$, MELD score $(p<0.001)$, and INR $(p=0.005)$, and correlated negatively with platelets count $(p=0.01)$.
\end{abstract}

Conclusion: Cirrhotic patients have higher serum betatrophin levels; moreover, these levels are positively correlated with disease severity as well as the emergence of insulin resistance.

Keywords: Liver cirrhosis, Insulin resistance, Human betatrophin protein

\section{Background}

The liver plays a vital role in glucose homeostasis; consequently, chronic liver disease results in disturbances in glucose metabolism. Insulin resistance (IR) is common in cirrhotic patients; it was reported that $57 \%$ of cirrhotic patients had IR [1]. This phenomenon was observed in cirrhotic patients even before the disturbance of glucose tolerance became prominent. Compensation for this hormonal resistance occurs by increasing the secretory capacity and $\beta$-cell mass $[2,3]$.

\footnotetext{
* Correspondence: ghadaabdelrahman@med.asu.edu.eg 'Department of Internal Medicine, Gastroenterology and Hepatology Unit, Faculty of Medicine, Ain Shams University, Cairo 11591, Egypt Full list of author information is available at the end of the article
}

Factors accounting for IR in the context of cirrhosis remain mostly undefined, although there has been evidence that there is a circulating factor associated with insulin-resistant states $[4,5]$. The identification of betatrophin hormone was reported by Douglas A. Melton's group [6]. It is a member of angiopoietin-like gene family (known as angiopoietin-like 8 (ANGPTL8)/Lipasin/ refeeding-induced fat and liver protein (RIFL) [7]. It is secreted under insulin-resistant conditions mainly from adipose tissue and liver $[8,9]$. There has been an increasing interest in serum betatrophin to better understand its role in human disease. It was reported that serum betatrophin levels were altered under specific physiological states such as the postprandial state [10] 
and pathological conditions such as type 1 and 2 diabetes [9-14].

The role of betatrophin in cirrhosis is still unknown, and scarce studies demonstrated the correlation of serum betatrophin levels and liver cirrhosis of different severities [15]. This study aimed to investigate the correlation of serum betatrophin levels with disease severity and the emergence of insulin resistance in cirrhotic patients.

\section{Methods}

This case-control study was carried out at Ain Shams University Hospitals. The participants were recruited from the outpatient clinic and in-patient ward of gastroenterology and hepatology unit of the internal medicine department, during the period from May 2017 till May 2018. Approval was obtained from the Ethics Committee of Faculty of Medicine, Ain Shams University. Informed written consent was obtained from each participant before enrollment in the study. This study was performed in accordance with the 1975 principles of the Declaration of Helsinki and its appendices.

Twenty-seven cirrhotic patients and 30 healthy controls with matched age and sex were consecutively enrolled in the study. Cirrhosis was diagnosed based on clinical, biochemical, ultrasonographic, or histological criteria. The exclusion criteria were patients who had undergone previous surgery for portal hypertension, patients suffering from bacterial infection or gastrointestinal bleeding, patients receiving vasoactive drugs within 14 days before the study, patients receiving medications known to affect body composition or lipid or glucose metabolism (e.g., thyroid medications, thiazolidinediones, metfor$\mathrm{min}$ ), and patients with renal disease, diabetes mellitus, renal failure, hypothyroidism, or Cushing's disease.

All participants were subjected to a detailed history taking, a thorough clinical examination, pelvi-abdominal ultrasound, and laboratory investigations including complete liver function tests, complete blood count, kidney function tests, fasting glucose level, and international normalized ratio (INR). The severity of cirrhosis was classified according to the Child-Pugh classification and the model for end-stage liver disease (MELD) scores $[16,17]$.

Serum insulin levels were measured using a recombinant human insulin Enzyme-Linked Immunosorbent Assay (ELISA) kit (Calbiotech ${ }^{\circ}$, CA, USA) with a standard detection range of $6.25-50 \mu \mathrm{IU} / \mathrm{mL}$ and a sensitivity of $6.25 \mu \mathrm{IU} / \mathrm{mL}$. IR was defined as a HOMA-IR score of greater than 2 according to Matthews et al. [18].

Human active betatrophin level was analyzed by a specific quantitative sandwich ELISA kit (Aviscera Bioscience $\left.^{\circ} \mathrm{AB}, \mathrm{CA}, \mathrm{USA}\right)$. The sensitivity of the assay was
Table 1 Comparison between liver cirrhosis patients and controls

\begin{tabular}{llll}
\hline Variable & $\begin{array}{l}\text { Liver cirrhosis } \\
(n=30)\end{array}$ & $\begin{array}{l}\text { Control } \\
(n=30)\end{array}$ & $p$ value \\
\hline Age (years) & $58(50-65)$ & $52.5(43-60)$ & 0.032 \\
Fasting glucose level $(\mathrm{mg} / \mathrm{dL})$ & $103 \pm 21.70$ & $81 \pm 22.55$ & 0.008 \\
Fasting insulin level $(\mu \mathrm{I} / \mathrm{mL})$ & $16(10-37)$ & $3.25(2-9)$ & $<0.001$ \\
HOMA-IR & $4.3(0.5-9.65)$ & $0.65(0.3-1.9)$ & 0.003 \\
Insulin resistance & $n=20(74 \%)$ & $n=7(23.3 \%)$ & $<0.001$ \\
Serum betatrophin level $(\mathrm{ng} / \mathrm{mL})$ & $20(15-30)$ & $8(4-12)$ & $<0.001$
\end{tabular}

Data are shown as median (IQR), mean $\pm \mathrm{SD}$, or number and percentage ( $n \& \%)$

$0.4 \mathrm{ng} / \mathrm{mL}$, and the intra and inter-assay reproducibility were $<6 \%$ and $<10 \%$, respectively.

\section{Statistical analysis}

Data were analyzed using Stata ${ }^{\circ}$ version 14.2 (StataCorp LLC, College Station, TX, USA). Normally distributed numerical data were presented as mean $\pm \mathrm{SD}$, and intergroup differences were compared using Student's $t$ test. Non-normally distributed numerical data were presented as median and interquartile range (IQR), and intergroup differences were compared using the Mann-Whitney $U$ test or Kruskal-Wallis test, as appropriate. Categorical data were presented as number and percentage, and differences were compared using Fisher's exact test (for nominal data) or the chi-squared test (for ordinal data). Multivariable binary logistic regression analysis was used to examine the relation between betatrophin and other variables as adjusted for possible confounding factors. Correlations were tested using the Spearman rank correlation. Receiver-operating characteristic (ROC) curve analysis was used to examine the diagnostic value of betatrophin in the prediction of IR. $p$ value $<0.05$ was considered statistically significant.

\section{Results}

The current study included 27 cirrhotic patients and 30 controls with a median age of 58 (50-65) and 52.5 (4360 ) years, respectively (Table 1 ). All of them were males with hepatitis $\mathrm{C}$ virus (HCV)-related liver cirrhosis. The cirrhosis group included 12 (44.4\%) and 15 (55.5\%) patients with Child-Pugh class B and C, respectively. Eight, 12 , and 7 cirrhotic patients had tense, moderate, and mild ascites, respectively.

Table 2 Determinants of insulin resistance

\begin{tabular}{lllll}
\hline Variable & $p$ value & \multirow{2}{*}{$\begin{array}{l}\text { Odds } \\
\text { ratio }\end{array}$} & & \multicolumn{2}{c}{$95 \% \mathrm{Cl}$} & \\
\cline { 5 - 6 } \cline { 4 - 5 } & & 0.97 & 0.82 & 1.16 \\
\hline Age & 0.808 & & Lower & Upper \\
Cirrhosis & $<0.001$ & 9.38 & 2.80 & 31.38 \\
Serum betatrophin level & 0.663 & 1.06 & 0.80 & 1.41 \\
\hline
\end{tabular}




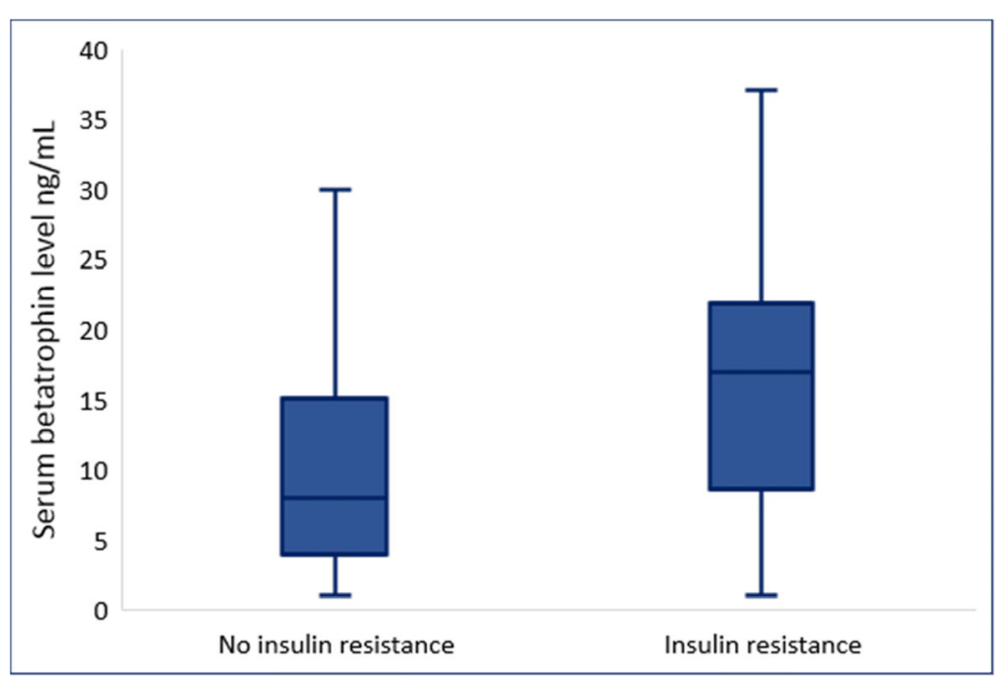

Fig. 1 Box plot showing serum betatrophin levels in subjects with and without insulin resistance

IR was observed in 20 (74\%) cirrhotic patients, whereas only 7 (23.3\%) controls had IR (Table 1$)$. Moreover, Child class $\mathrm{C}$ patients had higher HOMA-IR than those with Child class B cirrhosis; however, this difference was statistically insignificant [5.4 (1.15-12.3) vs 3 (0.5-7.22), respectively, $p=0.07$. Determinants of IR are shown in Table 2. Subjects with IR had higher serum betatrophin levels than those without IR with a median level (IQR) of $20(12-30)$ vs $8(4-15) \mathrm{ng} / \mathrm{mL}$, respectively $(p<0.001)$ (Fig. 1).

There was a statistically significant difference between cirrhotic patients and controls regarding serum betatrophin levels, fasting glucose levels, fasting insulin levels, HOMA-IR, and the prevalence of IR (Table 1, Fig. 2). Moreover, Child-Pugh class $C$ patients had a significantly higher serum betatrophin levels than those with Child-Pugh class B cirrhosis [22.25 (15.50$53.75)$ vs $15.50(8.87-21.37) \mathrm{ng} / \mathrm{mL}$, respectively, $p=$ 0.01] (Fig. 2). Additionally, the highest serum betatrophin levels were detected in patients with tense ascites followed by moderate and mild ascites [37 (15$60)$ vs $17.50(15-30)$ vs $13(2.5-22.5) \mathrm{ng} / \mathrm{mL}$, respectively, $p=0.01$ ] (Fig. 3).

In the cirrhosis group, serum betatrophin levels correlated positively with Child-Pugh score, MELD score, INR, fasting glucose levels, fasting insulin levels, and HOMA-IR and correlated negatively with platelets count (Table 3).

By ROC curve analysis, serum betatrophin cut-off level of $>16 \mathrm{ng} / \mathrm{mL}$ discriminated IR with AUROC of 0.759 , $95 \% \mathrm{CI}=0.631-0.860, p<0.001,64.3 \%$ sensitivity, and 90.6\% specificity (Fig. 4).

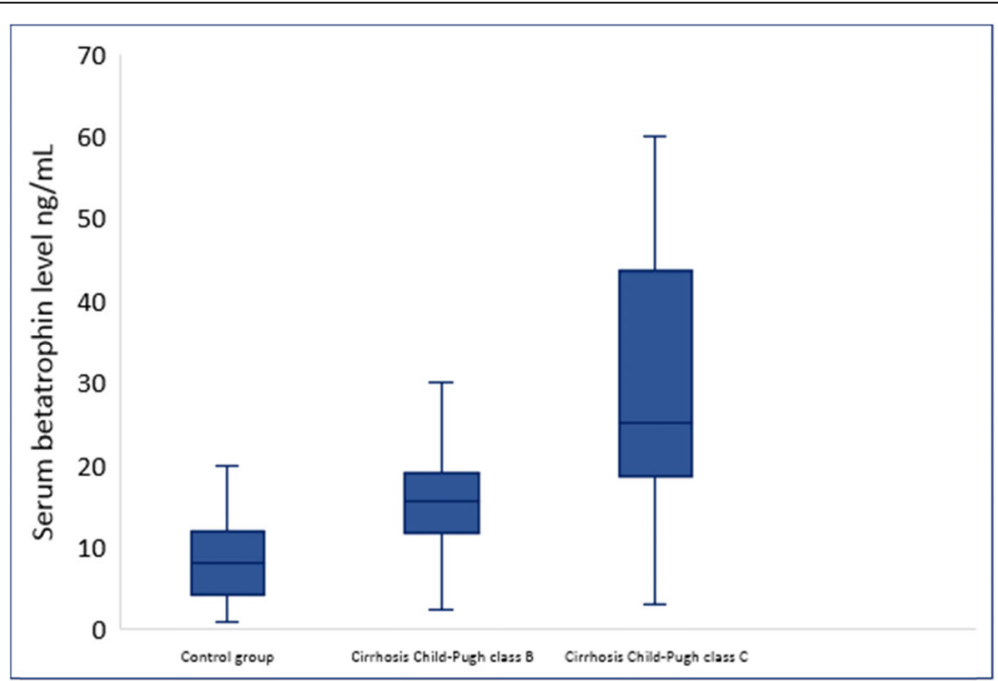

Fig. 2 Box plot showing serum betatrophin levels in patients with Child B and C cirrhosis and controls 


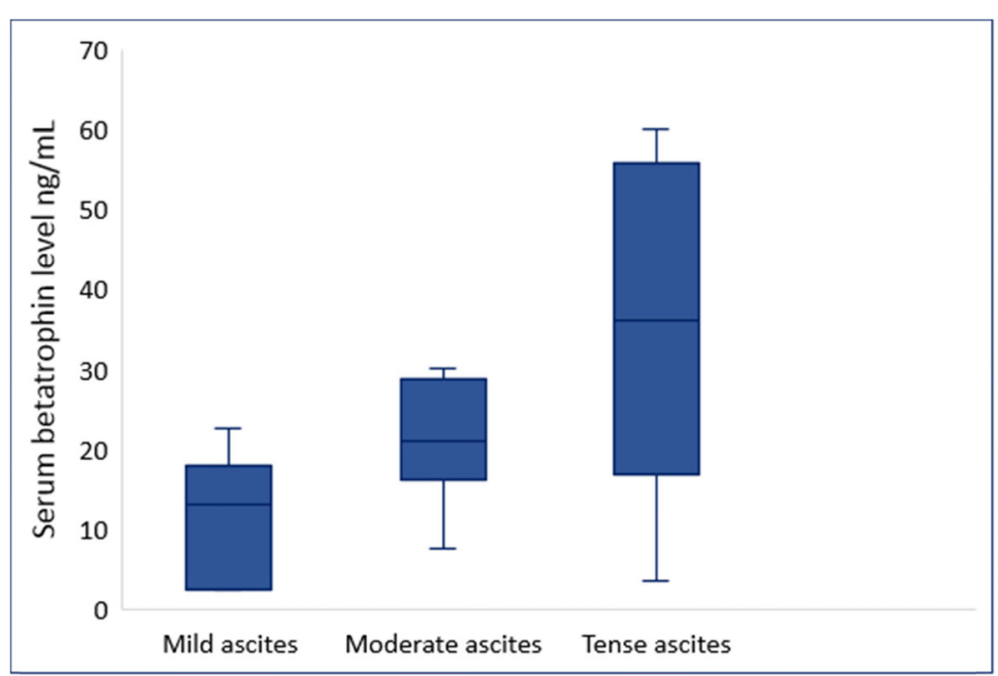

Fig. 3 Box plot showing serum betatrophin levels according to the degree of ascites

\section{Discussion}

Betatrophin is a novel protein that can enhance pancreatic islet $\beta$-cell mass resulting in improvement of glucose tolerance in mice models with IR [19]. Moreover, a correlation between serum betatrophin levels and IR indices was detected $[4,7,13]$.

It was postulated that IR may have a role in the early stages of hepatic disease progression [20]. There is evidence that insulin has a contribution to the pathogenesis of hepatic fibrosis and clinically significant portal hypertension through inducing the proliferation of hepatic stellate cells and modulating the endothelial synthesis of nitric oxide and endothelin [21-24]. Furthermore, IR was independently associated with significant fibrosis $[25,26]$, an increased risk of death, liver transplantation [27], and the development of hepatocellular carcinoma in chronic HCV patients [28].

Table 3 Correlations between serum betatrophin level and other variables in the cirrhosis group

\begin{tabular}{lll}
\hline Variable & \multicolumn{2}{l}{ Serum betatrophin level } \\
\cline { 2 - 3 } & Correlation coefficient & $p$ value \\
\hline Hemoglobin & -0.003 & 0.985 \\
Total leucocytic count & -0.215 & 0.280 \\
Platelets count & -0.468 & 0.013 \\
Serum albumin & -0.041 & 0.837 \\
International normalized ratio & 0.522 & 0.005 \\
Total bilirubin & 0.294 & 0.136 \\
Child-Pugh score & 0.435 & 0.023 \\
MELD score & 0.593 & 0.001 \\
Fasting blood glucose level & 0.589 & 0.001 \\
Fasting insulin level & 0.511 & 0.006 \\
HOMA-IR & 0.508 & 0.006 \\
\hline
\end{tabular}

The present study aimed to investigate the relationship between serum betatrophin levels and IR in cirrhotic patients and its relevance with the severity of the disease.

The present study confirms that IR is a frequent phenomenon in cirrhotic patients, and it is found in $74 \%$ of our patients. Also, there was a statistically significant difference in fasting blood glucose and insulin concentrations between cirrhotic patients and healthy controls. These findings agree with previous reports $[1,3,15,24]$. Additionally, in accordance with previous results [11], this study proves by using a multivariable binary logistic regression analysis the relationship between IR and cirrhosis.

Several mechanisms of hyperinsulinemia in chronic liver disease have been postulated. The most pronounced is an insufficient insulin clearance due to reduced hepatocellular function. Hyperinsulinemia will be aggravated with disease progression due to further impairment of hepatic function and portal hypertension-related portosystemic shunting of insulin [29, 30]. However, Greco et al. [31] suggested that increased serum insulin level is the result of increased $\beta$-cell sensitivity to glucose, whereas hepatic insulin extraction did not seem to contribute significantly in this condition. Chronic hyperinsulinemia then leads to insulin resistance via the desensitization and downregulation of insulin receptors.

In agreement with previous results [7,9], candidates who had IR had higher serum betatrophin levels than candidates without IR. Moreover, serum betatrophin levels correlated positively with IR indices and the HOMA-IR model.

Serum betatrophin levels were higher in cirrhotic patients compared to those of controls as reported previously [15]; moreover, Child-Pugh class $C$ patients had higher serum betatrophin levels than Child-Pugh class B 


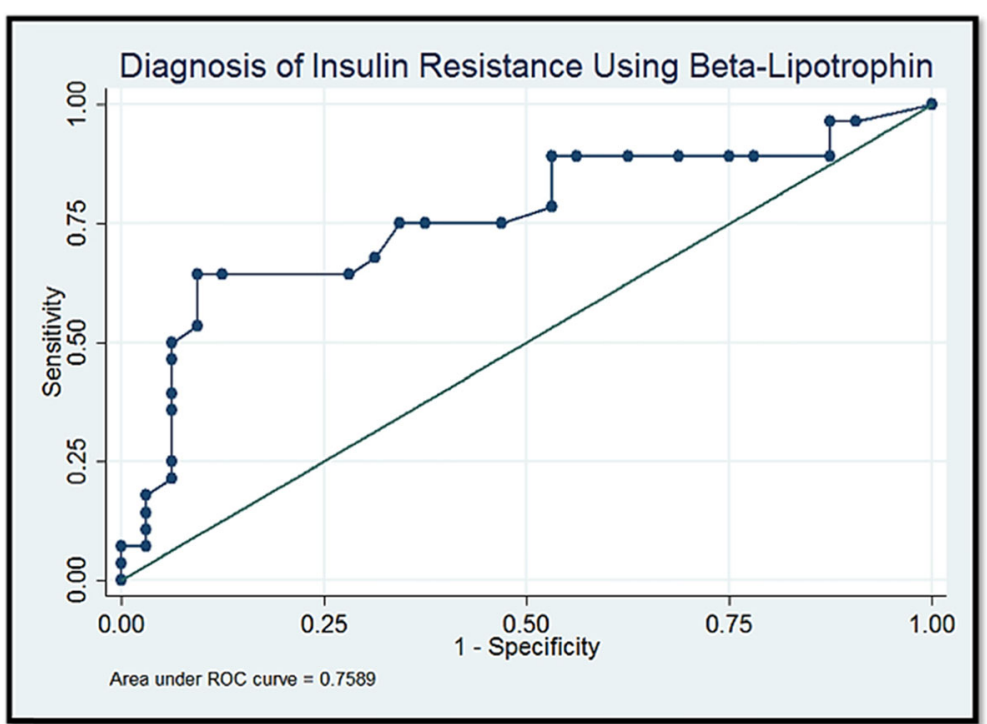

Fig. 4 ROC curve demonstrating the diagnostic performance of serum betatrophin in the prediction of insulin resistance

patients. Additionally, the present study is the first study to correlate between ascites and betatrophin levels; patients with tense ascites had the highest serum betatrophin levels followed by patients with moderate and mild ascites.

In the cirrhosis group, serum betatrophin levels correlated positively with Child-Pugh score, MELD score, and INR, and correlated negatively with platelets count. This is consistent with Arias-Loste et al. [15]. All the previous findings suggest that the serum betatrophin level is correlated with the severity of liver disease, and this may suggest that impaired clearance of betatrophin could contribute to increased serum betatrophin levels. Another possibility is that the increased betatrophin expression in liver and fat tissue in cirrhotic patients could be attributed to IR [14, 19, 32]. These preliminary results indicate that betatrophin may counterbalance, at least in part, IR in cirrhotic patients. Further studies are needed to confirm this possibility and to investigate the exact pathophysiology and the clinical application of this conclusion.

The present study is limited because we did not investigate the causal relationship between serum betatrophin and IR in cirrhotic patients, and only an association between both variables can be concluded.

\section{Conclusion}

Cirrhotic patients have higher serum betatrophin levels; moreover, these levels are positively correlated with disease severity as well as the emergence of insulin resistance. Further studies are needed to clarify the ultimate clinical utility of serum betatrophin in liver cirrhosis and glucose homeostasis.

\section{Abbreviations}

HOMA-IR: Homeostatic Model Assessment of Insulin Resistance; INR: International normalized ratio; IR: Insulin resistance; MELD: Model for end-stage liver disease

\section{Acknowledgements \\ Not applicable}

\section{Authors' contributions}

MS contributed in the conception and design of the work and the revision of the manuscript. WK contributed in the revision of the work and language polishing of the manuscript. SH contributed in the collection of data and in performing the statistical part of the work. GM contributed in the writing of the manuscript, revision of the work, and the publication process. All authors have read and approved the final manuscript.

\section{Funding}

This research did not receive any specific grant from funding agencies in the public, commercial, or not-for-profit sectors.

\section{Availability of data and materials}

The datasets used and analyzed during the current study are available from the corresponding author on reasonable request.

\section{Ethics approval and consent to participate}

Approval was obtained from the Ethics Committee of Faculty of Medicine, Ain Shams University (FWA 000017585). Informed written consent was obtained from each participant before enrollment in the study. This study was performed in accordance with the 1975 principles of the Declaration of Helsinki and its appendices.

Consent for publication

Not applicable

\section{Competing interests}

The authors declare that they have no competing interests.

\section{Author details}

'Department of Internal Medicine, Gastroenterology and Hepatology Unit, Faculty of Medicine, Ain Shams University, Cairo 11591, Egypt. ${ }^{2}$ Department of Clinical Pathology, Faculty of Medicine, Ain Shams University, Cairo 11591, Egypt. 
Received: 31 January 2020 Accepted: 28 May 2020

Published online: 10 August 2020

\section{References}

1. Megyesi C, Samols E, Marks V (1967) Glucose tolerance and diabetes in chronic liver disease. Lancet 2:1051-1056

2. Araújo TG, Oliveira AG, Saad MJ (2013) Insulin-resistance-associated compensatory mechanisms of pancreatic Beta cells: a current opinion. Front Endocrinol (Lausanne) 4:146

3. Goswami A, Bhargava N, Dadhich S, Kulamarva G (2014) Insulin resistance in euglycemic cirrhosis. Ann Gastroenterol 27:237-243

4. Bonner-Weir S (2000) Perspective: postnatal pancreatic beta cell growth. Endocrinology 141:1926-1929

5. Flier SN, Kulkarni RN, Kahn CR (2001) Evidence for a circulating islet cell growth factor in insulin-resistant states. Proc Natl Acad Sci U S A 98:7475-7480

6. Douglas MW, George J (2009) Molecular mechanisms of insulin resistance in chronic hepatitis C. World J Gastroenterol 15:4356-4364

7. Leiherer A, Muendlein A, Geiger K, Saely C, Brandtner E, Ebner J, Larcher B, Mader A et al (2018) Betatrophin is associated with type 2 diabetes and markers of insulin resistance. Diabetes 67(Supp 1) 2445-PUB

8. Zhang R, Abou-Samra AB (2014) A dual role of lipasin (betatrophin) in lipid metabolism and glucose homeostasis: consensus and controversy. Cardiovasc Diabetol 13:133

9. Chen X, Lu P, He W, Zhang J, Liu L, Yang Y, Liu Z, Xie J et al (2015) Circulating betatrophin levels are increased in patients with type 2 diabetes and associated with insulin resistance. J Clin Endocrinol Metab 100:E96-100

10. Espes D, Martinell M, Carlsson PO (2014) Increased circulating betatrophin concentrations in patients with type 2 diabetes. Int J Endocrinol 2014: 323407

11. Espes D, Lau J, Carlsson PO (2014) Increased circulating levels of betatrophin in individuals with long-standing type 1 diabetes. Diabetologia 57:50-53

12. Fu Z, Berhane F, Fite A, Seyoum B, Abou-Samra AB, Zhang R (2014) Elevated circulating lipasin/betatrophin in human type 2 diabetes and obesity. Sci Rep 4:5013

13. Gómez-Ambrosi J, Pascual E, Catalán V, Rodríguez A, Ramírez B, Silva C, Gil MJ, Salvador J et al (2014) Circulating betatrophin concentrations are decreased in human obesity and type 2 diabetes. J Clin Endocrinol Metab 99:E2004-E2009

14. Hu H, Sun W, Yu S, Hong X, Qian W, Tang B, Wang D, Yang L et al (2014) Increased circulating levels of betatrophin in newly diagnosed type 2 diabetic patients. Diabetes Care 37:2718-2722

15. Arias-Loste MT, García-Unzueta MT, Llerena S, Iruzubieta P, Puente A, Cabezas J, Alonso C, Cuadrado A et al (2015) Plasma betatrophin levels in patients with liver cirrhosis. World J Gastroenterol 21:10662-10668

16. Pugh RN, Murray-Lyon IM, Dawson JL, Pietroni MC, Williams R (1973) Transection of the oesophagus for bleeding oesophageal varices. Br J Surg 60:646-649

17. Malinchoc M, Kamath PS, Gordon FD, Peine CJ, Rank J, ter Borg PC (2000) A model to predict poor survival in patients undergoing transjugular intrahepatic portosystemic shunts. Hepatology 31:864-871

18. Matthews DR, Hosker JP, Rudenski AS, Naylor BA, Treacher DF, Turner RC (1985) Homeostasis model assessment: insulin resistance and beta-cell function from fasting plasma glucose and insulin concentrations in man. Diabetologia 28:412-419

19. Yi P, Park J-S, Melton DA (2013) Betatrophin: a hormone that controls pancreatic $\beta$ cell proliferation. Cell 153:747-758

20. Francque S, Verrijken A, Mertens I, Hubens G, Van Marck E, Pelckmans P, Michielsen P, Van Gaal L (2011) Visceral adiposity and insulin resistance are independent predictors of the presence of non-cirrhotic NAFLD-related portal hypertension. Int J Obes 35:270-278

21. Vincent MA, Montagnani M, Quon MJ (2003) Molecular and physiologic actions of insulin related to production of nitric oxide in vascular endothelium. Curr Diab Rep 3:279-288

22. Rockey DC (2006) Hepatic fibrosis, stellate cells, and portal hypertension. Clin Liver Dis 10:459-479

23. Iwakiri Y, Groszmann RJ (2007) Vascular endothelial dysfunction in cirrhosis. J Hepatol 46:927-934

24. Erice E, Llop E, Berzigotti A, Abraldes JG, Conget I, Seijo S, Reverter E, Albillos A et al (2012) Insulin resistance in patients with cirrhosis and portal hypertension. Am J Physiol Gastrointest Liver Physiol 302:G1458-G1465
25. Moucari R, Asselah T, Cazals-Hatem D, Voitot H, Boyer N, Ripault MP, Sobesky R, Martinot-Peignoux M et al (2008) Insulin resistance in chronic hepatitis C: association with genotypes 1 and 4, serum HCV RNA level, and liver fibrosis. Gastroenterology 134:416-423

26. Petta S, Cammà C, Di Marco V, Alessi N, Cabibi D, Caldarella R, Licata A, Massenti F et al (2008) Insulin resistance and diabetes increase fibrosis in the liver of patients with genotype 1 HCV infection. Am J Gastroenterol 103: 1136-1144

27. Nkontchou G, Bastard JP, Ziol M, Aout M, Cosson E, Ganne-Carrie N, Grando-Lemaire V, Roulot D et al (2010) Insulin resistance, serum leptin, and adiponectin levels and outcomes of viral hepatitis C cirrhosis. J Hepatol 53: 827-833

28. Hung $\mathrm{CH}$, Wang $\mathrm{JH}$, Hu TH, Chen $\mathrm{CH}$, Chang $\mathrm{KC}$, Yen $\mathrm{YH}$, Kuo $\mathrm{YH}$, Tsai MC et al (2010) Insulin resistance is associated with hepatocellular carcinoma in chronic hepatitis C infection. World J Gastroenterol 16:2265-2271

29. Kaser S, Föger B, Waldenberger P, Nachbaur K, Propst A, Jaschke W, Vogel W, Patsch JR (2000) Transjugular intrahepatic portosystemic shunt (TIPS) augments hyperinsulinemia in patients with cirrhosis. J Hepatol 33:902-906

30. Grancini V, Trombetta M, Lunati ME, Zimbalatti D, Boselli ML, Gatti S, Donato MF, Resi $V$ et al (2015) Contribution of $\beta$-cell dysfunction and insulin resistance to cirrhosis-associated diabetes: Role of severity of liver disease. J Hepatol 63:1484-1490

31. Greco AV, Mingrone G, Mari A, Capristo E, Manco M, Gasbarrini G (2002) Mechanisms of hyperinsulinaemia in Child's disease grade B liver cirrhosis investigated in free living conditions. Gut 51:870-875

32. Raghow R (2013) Betatrophin: A liver-derived hormone for the pancreatic $\beta$ cell proliferation. World J Diabetes 4:234-237

\section{Publisher's Note}

Springer Nature remains neutral with regard to jurisdictional claims in published maps and institutional affiliations.

\section{Submit your manuscript to a SpringerOpen ${ }^{\circ}$ journal and benefit from:}

- Convenient online submission

- Rigorous peer review

- Open access: articles freely available online

High visibility within the field

- Retaining the copyright to your article

Submit your next manuscript at $>$ springeropen.com 